\title{
Is chemoprophylaxis with ivermectin in dentistry effective at preventing COVID-19?
}

\author{
A quimioprofilaxia com ivermectina em odontologia \\ é eficaz na prevenção da COVID-19?
}

\author{
Marcos Luciano Pimenta PINHEIRO1 iD https://orcid.org/0000-0001-9939-1045 \\ Ricardo Lopes ROCHA ${ }^{2}$ iD https://orcid.org/0000-0002-6252-5246 \\ Melissa Monteiro GUIMARÃES ${ }^{3}$ iD https://orcid.org/0000-0001-6773-4920
}

Due to the serious problems caused by the COVID-19 pandemic, several publications have proposed prevention protocols for infection by Sars-CoV-2 [1-4]. This has led dentists to seek information on chemoprophylaxis, since dental staff must provide care for patients with urgent need [5].

Ivermectin has antiviral effects on viruses whose genetic material is DNA and those the present RNA, as is the case of the novel coronavirus [6]. The most widely accepted mechanism of action for ivermectin is the inhibition of the nuclear importation of viral proteins mediated by the heterodimer importin $\alpha / \beta 1$, which are indispensable to the replication of RNA viruses [7].

Caly et al. [8] demonstrated the effect of ivermectin on Sars-CoV-2. The authors found that the continuous use of 5 microM of ivermectin for two days in an isolated culture of Vero/hSLAM cells infected with Sars-CoV-2 killed the novel coronavirus nearly completely [8]. Despite this promising discovery, the activity of ivermectin has not yet been clinically proven in humans.

Regarding pharmacokinetics, in its daily release on evidence related to COVID-19 [9], the Brazilian Health Ministry presented a study in which the authors report that doses that produce inhibitory concentrations of SARSCoV-2 cannot be achieved in humans, as the maximum dose permitted by the US Food and Drug Administration (FDA) is $200 \mathrm{mg} / \mathrm{kg}$ [10] and safe therapeutic doses reach blood levels in the range of 20 to $80 \mathrm{ng} / \mathrm{ml}$ [11] Caly et al. [8] report that ivermectin has an in vitro inhibitory concentration (IC50) of SARS-CoV-2 35 fold higher than the maximum plasma concentration (Cmax) reached after the oral administration of the approved dose of ivermectin for administration to humans [8] This observation limits the execution of tests on humans and suggests a low likelihood of success regarding the treatment of COVID-19 [12,13].

After noting an increase in the consumption of ivermectin, the FDA warned the population regarding the

1 Universidade Federal dos Vales do Jequitinhonha e Mucuri, Faculdade de Ciências Biológicas e da Saúde, Departamento de Ciências Básicas. Campus JK, Rodovia MGT 367, km 583, 5000, Alto da Jacuba, Diamantina, MG, Brasil. Correspondence to: MLP PINHEIRO. E-mail: $<$ marcospimenta2@gmail.com>.

2 Universidade Federal dos Vales do Jequitinhonha e Mucuri, Faculdade de Ciências Biológicas e da Saúde, Departamento de Odontologia. Diamantina, MG, Brasil.

3 Universidade Federal dos Vales do Jequitinhonha e Mucuri, Faculdade de Ciências Biológicas e da Saúde, Departamento de Ciências Básicas. Diamantina, MG, Brasil.

$\boldsymbol{\nabla} \mathbf{v}$

How to cite this article

Pinheiro MLP, Rocha RL, Guimarães MM. Is chemoprophylaxis with ivermectin in dentistry effective at preventing COVID-19?. RGO, Rev Gaúch Odontol. 2021;69:e20210025. http://dx.doi.org/10.1590/1981-86372021002520200133 
side effects and to not use veterinary products, not to use products of a dubious origin, not to take the medication without a medical prescription and only take drugs dispensed by pharmacists at regulated pharmacies [14]

Ivermectin is considered safe, with few side effects when taken orally [6] However, its concomitant use with another antiviral medication is associated with neurotoxicity [15] The Brazilian Society of Pneumology and Phthisiology reports that there is no scientific evidence that ivermectin, chloroquine or hydroxychloroquine, either alone or in combination, is capable of avoiding the installation of the disease in non-infected individuals [16] There are four ongoing studies that are expected to be concluded between August and December 2020, the results of which could lead to changes in the recommendations if clinical benefits are demonstrated [17]

The administration of ivermectin in hospitalized patients has been associated with a shorter hospital stay and a reduction in the mortality rate [18]. To date, however, there is no robust scientific evidence attesting to the effectiveness and safety of ivermectin as chemoprophylaxis for COVID-19.

\section{REFERENCES}

1. Ather A, Patel B, Ruparel NB, Diogenes A, Hargreaves KM. Coronavirus disease 19 (COVID-19): implications for clinical dental care. J Endod. 2020;46(5):584-595. http://dx.doi. org/10.1016/j.joen.2020.03.008

2. Ahmed MA, Jouhar R, Ahmed N, Adnan S, Aftab M, Zafar MS, et al. Fear and practice modifications among dentists to combat novel coronavirus disease (COVID-19) outbreak. Int J Environ Res Public Health. 2020 Apr 19;17(8):2821. http:// dx.doi.org/10.3390/ijerph17082821.

3. Baghizadeh Fini M. What dentists need to know about COVID-19. Oral Oncol. 2020 Jun;105:104741. http://dx.doi. org/10.1016/j.oraloncology.2020.104741

4. Alharbi A, Alharbi S, Alqaidi S. Guidelines for dental care provision during the COVID-19 pandemic. Saudi Dent J. 2020;32(4):181-186. http://dx.doi.org/10.1016/j.sdentj.2020.04.001

5. Coulthard P. Dentistry and coronavirus (COVID-19) - moral decision-making. Br Dent J. 2020;228(7):503-505. http:// dx.doi.org/10.1038/s41415-020-1482-1

6. Heidary F, Gharebaghi R. Ivermectin: a systematic review from antiviral effects to COVID-19 complementary regimen. J Antibiot (Tokyo). 2020;73(9):593-602. http://dx.doi.org/10.1038/ s41429-020-0336-z

7. Wagstaff KM, Sivakumaran $H$, Heaton SM, Harrich D, Jans $D A$. Ivermectin is a specific inhibitor of importin $\alpha / \beta$-mediated nuclear import able to inhibit replication of HIV-1 and dengue virus. Biochem J. 2012;443(3):851-856. http://dx.doi. org/10.1042/BJ20120150.
8. Caly L, Druce JD, Catton MG, Jans DA, Wagstaff KM. The FDA-approved drug ivermectin inhibits the replication of SARS-CoV-2 in vitro. Antiviral Res. 2020 Jun;178:104787. http://dx.doi.org/10.1016/j.antiviral.2020.104787

9. Brasil. Ministério da Saúde. Informe Diário de Evidências - covid-19. Brasília (DF); [cited 2020 jul 9]. Available from: <http://portalarquivos.saude.gov.br/images/pdf/2020/ April/20/InformeDiario-referente-20-04.pdf>

10. Guzzo CA, Furtek Cl, PorrasAG, ChenC, Tipping R, Clineschmidt $\mathrm{CM}$, et al. Safety, tolerability, and pharmacokinetics of escalating high doses of ivermectin in healthy adult subjects. J Clin Pharmacol. 2002 Oct;42(10):1122-1133. http://dx.doi. org/10.1177/009127002401382731

11. Canga AG, Prieto AMS, Liébana MJD, Martínez NF, Vega MS, Vieitez JJG. The pharmacokinetics and interactions of ivermectin in humans--a mini-review. AAPS J. 2008;10(1):42-46. http://dx.doi.org/10.1208/s12248-007-9000-9

12. Schmith VD, Zhou JJ, Lohmer LRL. The Approved Dose of Ivermectin Alone is not the Ideal Dose for the Treatment of COVID-19. Clin Pharmacol Ther. 2020;108(4):762-765. http://dx.doi.org/10.1002/cpt.1889

13. Momekov G, Momekova D. Ivermectin as a potential COVID-19 treatment from the pharmacokinetic point of view: antiviral levels are not likely attainable with known dosing regimens. Biotechnol Biotec Eq. 2020;34:1, 469-474. http:// dx.doi.org/10.1080/13102818.2020.1775118

14. Food and Drug Administration. FDA Letter to Stakeholders: Do Not Use Ivermectin Intended for Animals as Treatment for COVID-19 in Humans. Washington (DC), 2020. [cited 2020 Jul 9]. Available from: <https://www.fda.gov/animal-veterinary/ product-safety-information/fda-letter-stakeholders-donot-use-ivermectin-intended-animals-treatment-covid-19humans>

15. Chandler RE. Serious Neurological Adverse Events after Ivermectin-Do They Occur beyond the Indication of Onchocerciasis? Am J Trop Med Hyg. 2018;98(2):382-388. http://dx.doi.org/10.4269/ajtmh.17-0042

16. Sociedade Brasileira de Pneumologia e Tisiologia. Posicionamento da SBPT acerca da profilaxia e tratamento da COVID-19. Brasília (DF), 2020. [cited 2020 Jul 9]. Available from: <https:// sbpt.org.br/portal/wp-content/uploads/2020/06/Profilaxia-etratamento-COVID-19.pdf>

17. Pan American Health Organization. Ongoing Living Update of Potential COVID-19 Therapeutics: summary of rapid systematic reviews. Washington (DC), 2020. [cited 2020 July 09]. Available from: <https://www.paho.org/en/documents/ ongoing-living-update-potential-covid-19-therapeuticssummary-rapid-systematic-reviews>

18. Patel AN, Desai SS, Grainger DW, Mehra MR. Usefulness of Ivermectin in COVID-19 Illness (April 6, 2020). [cited 2020 July 09]. Available from: <http://www. proyectodime.info/ documents/219/Utilidad_de_la_ivermectina.pdf>

19. Patel AN, Desai SS, Grainger DW, Mehra MR. Ivermectin in COVID-19 Related Critical Illness [retracted] [cited 2020 July 09]. Available from: https://www.isglobal.org/ documents/10179/6022921/Patel+et+al.+2020+version+1.pdf

Received on: 31/7/2020 Approved on: 15/10/2020 